cemoti $\begin{aligned} & \text { Cahiers d'études sur la Méditerranée } \\ & \text { orientale et le monde turco-iranien }\end{aligned}$

39-40 | 2006

Nos vingt ans : Berlin-Kashgar

\title{
Les migrations dans le monde turco-iranien
}

\section{Stéphane de Tapia}

\section{OpenEdition}

Journals

Édition électronique

URL : http://journals.openedition.org/cemoti/1774

DOI : $10.4000 /$ cemoti. 1774

ISSN : $1777-5396$

Éditeur

AFEMOTI

Édition imprimée

Date de publication : 16 octobre 2006

ISSN : 0764-9878

Référence électronique

Stéphane de Tapia, «Les migrations dans le monde turco-iranien », Cahiers d'études sur la Méditerranée orientale et le monde turco-iranien [En ligne], 39-40 | 2006, mis en ligne le 24 octobre 2006, consulté le 08 septembre 2020. URL : http://journals.openedition.org/cemoti/1774 ; DOI : https://doi.org/ 10.4000/cemoti. 1774

Ce document a été généré automatiquement le 8 septembre 2020

Tous droits réservés 


\title{
Les migrations dans le monde turco- iranien
}

\author{
Stéphane de Tapia
}

RÉSUMÉS

Sans être une revue spécialisée sur le thème des migrations internationales, la participation des CEMOTI à la diffusion des connaissances sur les migrations et mobilités est importante. Cependant, l'objectif de cette contribution n'est pas de faire un bilan des travaux des CEMOTI, mais de proposer un bilan, toujours provisoire, des connaissances sur les migrations dans la région « Méditerranée orientale / monde turco-iranien ». 